\title{
In vitro and in vivo hypolipidemic properties of the aqueous extract of Spirulina platensis, cultivated in colored flasks under artificial illumination
}

\author{
Mahmoud Al-Saman ${ }^{1}$, Nada Doleib ${ }^{2,3}$, Mohamed Ibrahim ${ }^{1}$, Mohamed Nasr $^{4}$, Ahmed Tayel ${ }^{5}$, Ragaa Hamouda ${ }^{\text {Corresp. }}$ \\ 2,6 \\ ${ }^{1}$ Department of Industrial Biotechnology,., Genetic Engineering and Biotechnology Research Institute, University of Sadat City, Sadat city, el monfya, \\ Egypt \\ 2 Department of Biology, Faculty of Sciences and Arts Khulais, University of Jeddah, jedda, Jedda, Saudi Arabia \\ 3 Department of Microbiology, Faculty of Applied and Industrial Science, University of Bahri, Khartoum, Sudan \\ 4 Department of Molecular Biology, Genetic Engineering and Biotechnology Research Institute, University of Sadat City, Sadat city, el monfya, Egypt \\ 5 Faculty of Aquatic and Fisheries Sciences, Kafrelsheikh University, Egypt, Kafrelsheikh, Egypt \\ 6 Department of Microbial Biotechnology,, Genetic Engineering and Biotechnology Research Institute, University of Sadat City, Sadat city, el monfya, \\ Egypt \\ Corresponding Author: Ragaa Hamouda \\ Email address: ragaa.hamouda@gebri.usc.edu.eg
}

Background: Spirulina is blue - green algae that grows mainly in tropical and subtropical lakes and is commonly used due to its nutritional features including high concentrations of protein, vitamins, mineral salts, carotenoids and antioxidants. This study aimed to investigate the anti-hypercholesterolemic potential of aqueous extract of Spirulina platensis cultivated in different colored flasks under artificial illumination; in vitro and in the diet induced hypercholesterolemic Swiss albino mice.

Methods: Spirulina platensis was cultivated in red, blue, green and colorless Erlenmeyer flasks containing Zarrouk's medium under aerobic conditions, with incessant illumination by artificial cool white fluorescent with light intensity of $2500 \mathrm{lux}\left(35 \mu \mathrm{mol}\right.$ photon $\mathrm{m}^{-2} \mathrm{~s}^{-1}$ ). Chlorophyll a and total carotenoid contents were estimated using colorimetric methods, fatty acids composition was determined by GCMass, in vitro and in vivo anti-cholesterol assays were used in assessing the anti-hypercholesterolemia potential of obtained Spirulina cells.

Results: The results showed that the highest cell dry weight, chlorophyll a, and carotenoid of $S$. platensis were observed in colorless flasks and that the lowest values were recorded with the green colored flasks. Also, the hot water extract of $S$. platensis obtained from colorless flasks at a concentration of $15 \mathrm{mg} / \mathrm{mL}$ after $60 \mathrm{~min}$ of incubation exhibited the greatest reduction of cholesterol level. Gas chromatography-mass spectrometry (GC-MS) analysis of S. platensis methanolic extract showed 15 bioactive compounds were identified and grouped according to their chemical structures. An experimental model of hypercholesterolemic mice had been examined for impact of S. platensis individually and combined with atorvastatin drug. All S. platensis groups resulted in a remarkable decrease in plasma total cholesterol (TC), triglycerides (TG) and low density lipoprotein (LDL); and increase in high density lipoprotein (HDL).

Conclusion: The present study concluded that the hot aqueous extract of $S$. platensis developed in colorless flasks is recommended as natural source for bioactive compounds, with anti-cholesterol and antioxidant potentialities. 


\section{In vitro and in vivo hypolipidemic properties of the aqueous extract}

2 of Spirulina platensis, cultivated in colored flasks under artificial

3 illumination

4

5 Mahmoud A. Al-Saman', Nada M. Doleib ${ }^{2,3}$, Mohamed R. Ibrahim ${ }^{1}$,

6 Mohamed Y Nasr ${ }^{4}$, Ahmed A. Tayel ${ }^{5}$, Ragaa A. Hamouda ${ }^{2,6^{*}}$

7

${ }^{1}$ Department of Industrial Biotechnology, Genetic Engineering and Biotechnology Research

$9 \quad$ Institute, University of Sadat City, Sadat City, Egypt

$10{ }^{2}$ Department of Biology, Faculty of Sciences and Arts Khulais, University of Jeddah, Jeddah,

11 Saudi Arabia

$12{ }^{3}$ Department of Microbiology, Faculty of Applied and Industrial Science, University of Bahri,

13 Khartoum, Sudan

${ }^{4}$ Department of Molecular Biology, Genetic Engineering and Biotechnology Research Institute,

University of Sadat City, Sadat City, Egypt

${ }^{5}$ Faculty of Aquatic and Fisheries Sciences, Kafrelsheikh University, Egypt

${ }^{6}$ Department of Microbial Biotechnology, Genetic Engineering and Biotechnology Research Institute, University of Sadat City, Sadat City, Egypt

\section{*Correspondence}

Ragaa A. Hamouda, Genetic Engineering and Biotechnology Research Institute, University of

Sadat City, El-Sadat City, Egypt 


\section{E-mail: ragaahom@yahoo.com}

\section{ABSTRACT}

ragaa.hamouda@gebri.usc.edu.eg

Background: Spirulina is blue - green algae that grows mainly in tropical and subtropical lakes and is commonly used due to its nutritional features including high concentrations of protein, vitamins, mineral salts, carotenoids and antioxidants. This study aimed to investigate the anti-hypercholesterolemic potential of aqueous extract of Spirulina platensis cultivated in different colored flasks under artificial illumination; in vitro and in the diet induced hypercholesterolemic Swiss albino mice. Methods: Spirulina platensis was cultivated in red, blue, green and colorless Erlenmeyer flasks containing Zarrouk's medium under aerobic conditions, with incessant illumination by artificial cool white fluorescent with light intensity of $2500 \mathrm{lux}\left(35 \mu \mathrm{mol}\right.$ photon $\left.\mathrm{m}^{-2} \mathrm{~s}^{-1}\right)$. Chlorophyll a and total carotenoid contents were estimated using colorimetric methods, fatty acids composition was determined by GC-Mass, in vitro and in vivo anti-cholesterol assays were used in assessing the anti-hypercholesterolemia potential of obtained Spirulina cells. Results: The results showed that the highest cell dry weight, chlorophyll a, and carotenoid of S. platensis were observed in colorless flasks and that the lowest values were recorded with the greencolored flasks. Also, the hot water extract of $S$. platensis obtained from colorless flasks at a concentration of $15 \mathrm{mg} / \mathrm{mL}$ after $60 \mathrm{~min}$ of incubation exhibited the greatest reduction of cholesterol level. Gas chromatography-mass spectrometry (GC-MS) analysis of S. platensis methanolic extract showed 15 bioactive compounds were identified and grouped according to their chemical structures. An experimental model of hypercholesterolemic mice had been examined for impact of $S$. platensis individually and combined with atorvastatin drug. All S. platensis groups resulted in a remarkable decrease in plasma total cholesterol (TC), 
54 triglycerides (TG) and low density lipoprotein (LDL); and increase in high density

55 lipoprotein (HDL). Conclusion: The present study concluded that the hot aqueous extract

56 of S. platensis developed in colorless flasks is recommended as natural source for bioactive

57 compounds, with anti-cholesterol and antioxidant potentialities.

58 Keywords: Spirulina platensis, cholesterol, hypolipidemic, in vivo, GC-MS, colored flasks

59

60

\section{INTRODUCTION}

Cholesterol is an important organic molecule of the cell membranes, and a precursor for the biosynthesis of bile acids, steroid hormones, and vitamin D. Cholesterol plays an essential role in human heart health. High-density lipoprotein (HDL) is considered as "good cholesterol" and low-density lipoprotein (LDL) is known as "bad cholesterol". High cholesterol in serum is a preceding risk factor for human cardiovascular disease (CVD) (Tabas, 2002). CVD for instance coronary heart disease is one of the major causes of death and other disabilities in developing countries (Nascimento et al., 2002).

Cholesterol in the human body is formed in the liver or straightly absorbed from the diet such as animal fat-based foods but in different quantities (William, 2003). Most ingested cholesterol is esterified within seven to ten hours after ingestion (Soliman, 2018), which causes it to be poorly absorbed by the gut. The body also compensates for absorption ingested cholesterol by reducing its own cholesterol synthesis (Lecerf and de Lorgeril, 2011).

Various drugs are used to lower blood cholesterol levels. Statins are a widely prescribed class of drugs to lower cholesterol, include for example atorvastatin, lovastatin and simvastatin. Statins inhibit the de novo synthesis of cholesterol via inhibition of HMG-CoA reductase enzyme in the liver that is responsible for making cholesterol (Ward et al., 2019). However, such drugs are expensive, and undesirable side effects have been reported, such as 
muscle pain, liver inflammation, type II diabetes and neurological side effects. This has logically allowed patients to search for alternative safe options, such as weight reduction, use of dietary supplements, fat-free diets and exercise (Michael et al., 2016).

Algae are photosynthetic organisms (photoautotrophs) that are capable of photosynthesis by sunlight or artificial light. Microalgae have higher growth rates, and larger quantities of highvalue products, such as pigments and dietary supplements (Zeng et al., 2011). Therefore, at present microalgae are under limelight worldwide due to its importance. The cultivation of algae can be done in open systems like raceway ponds (Vardaka et al., 2016), or in closed photobioreactors for instance, vertical-column, flat plate and tubular photobioreactors (Sanchez Miron, 2002; Samson and Leduy, 1985; Kaewpington et al., 2007); and both are used commercially. Most algal culture systems rely on Beer-Lambert's law to determine the light intensity $(I)$ depending on the depth of culture and the concentration of biomass. High values of $I$ promote growth parameters, while low values result in a biomass that is rich in pigments and proteins (Soni et al., 2017).

Artificial light provides better regulation of intensity, duration, and light spectra, usually involves fluorescent lamps, incandescent, or halogen lights which have wide emission spectra. Light characteristics have a profound influence on microalgae metabolism and development. Barufi et al., (2015) reported that growth rates were higher in Gracilaria birdiae exposed to white light, and Sharmila et al., (2018) concluded that the yellow color light could be used for the more lipid production, whereas blue light for biomass and pigments.

Spirulina is a blue-green algae that grows primarily in tropical and subtropical lakes and is widely used due to its nutritional features including high concentrations of protein $(\sim 60 \%)$ of its dry weight, vitamins (B1, $\mathrm{B}_{2}, \mathrm{~B}_{3}, \mathrm{~B}_{6}, \mathrm{~B}_{9}, \mathrm{~B}_{12}, \mathrm{C}, \mathrm{D}$ and $\left.\mathrm{E}\right)$, mineral salts (mainly, potassium 
100 and iron), carotenoids, and antioxidants (Gutiérrez-Salmeán et al., 2015). The United Nations

101 world at food conference declared that Spirulina as the best food for future (Pulz and Gross,

102 2004). Spirulina platensis had the pharmacological analyses which revealed the beneficial

103 properties in both in vitro and in vivo, including antioxidant (González de Rivera et al., 1993),

104 immunomodulation (Yang et al., 1997; Kim et al., 1998) antiviral (Abed et al., 2009), 105 anticancer (Gantar and Svircev, 2008), cholesterol reduction (Ponce-Canchihuaman et al., 106 2010), and anti-diabetes (Layam and Reddy, 2006) activities. S. platensis is the heaviest algal 107 source of Gamma-linolenic acid ( $\gamma$-linolenic acid; GLA), a precursor for the biologically-active 108 compounds (prostaglandins, PG) (Habib et al., 2008).

Based on, the previous studies that assume that algae may play a critical role in regulating

110 lipid metabolism in animals and humans and other results that suggest that color lights have

111 influence on regulating algal growth, and photosynthetic pigments synthesis. The purpose of this

112 experimental study is to grow S. platensis in flasks of different colors (Red, blue, green and 113 colorless) using Zarrouk's medium at constant light intensity

i. To analyze the different growth parameters such as biomass productivity and pigment content under artificial illumination

ii. To study the influence of the hot water extract of S. platensis biomass, obtained from the colored flasks on cholesterol levels reduction in vitro and in vivo animal model.

iii. To extract and analysis of fatty acids composition of S. platensis by gas chromatography-mass spectrometer (GC-Mass).

\section{MATERIALS AND METHODS}

\section{Algal cultures}


124 Genetic Engineering and Biotechnology Research Institute, University of Sadat City, Egypt

125 (Hamouda et al., 2016).

126 Culture maintenance

The blue green alga S. platensis was sustained on Zarrouk's medium (Zarrouk, 1966;

Belay, 1997) having the subsequent constituents Table (1):

129

130

131

132

133

134

135

136

137

138

139

140

141

142

143

144

145

\section{The effect of colored flasks on cell dry weight}

Red, blue, green and colorless Erlenmeyer flasks containing Zarrouk's medium were used for culturing S. platensis. All flasks including $100 \mathrm{~mL}$ of selected media under aerobic conditions, were autoclaved for $20 \mathrm{~min}$ at $121^{\circ} \mathrm{C}$, then incubated at $26 \pm 2^{\circ} \mathrm{C}$ with incessant illumination by cool white fluorescent with light intensity of 2500 lux $\left(35 \mu \mathrm{mol} \mathrm{m} \mathrm{m}^{-2} \mathrm{~s}^{-1}\right)$, after that left to grow with two times daily shaking to avoid algal cell clumping and adherence of algal cells to the containers. Cultures were gathered after 2 weeks by centrifugation at $5000 \mathrm{rpm}$ (Centurion Scientific LTD Model 1020 series) for 10 min and washed well with distilled water (Hamouda et al., 2016).

The algal biomass was evaluated by measuring its dry weight. All samples were filtered using filter paper (pore size $8 \mathrm{~mm}$ ), washed with distilled water, and dried at $60-65^{\circ} \mathrm{C}$ till constant weights (Nigam, 2007).

\section{Pigments estimation}

A known volume of $S$. platensis culture was centrifuged at $8000 \mathrm{rpm}$ for $10 \mathrm{~min}$, and then S. platensis pellets were treated with the same volume of $90 \%$ acetone, kept in water bath for 30 $\min$ at $55^{\circ} \mathrm{C}$, and followed by centrifugation once again at $8000 \mathrm{rpm}$ for $10 \mathrm{~min}$. The color of pellets must be white to guarantee complete extraction of pigments, after that supernatant was 
146 collected and then the absorbance was measured at three different wavelengths 663, 645 and 480

$147 \mathrm{~nm}$. Calculations were made according to the formula devised by the method of Jeffrey and

148 Humphery, (1975) for chlorophyll a, and Ridley, (1977) for total carotenoid estimation.

149 Chlorophyll $\mathrm{a}=\left[12.7 \mathrm{~A}_{663}-2.69 \mathrm{~A}_{645}\right] \times$ vol. of extraction / weight of the sample

150 where $\mathrm{A}_{663}$ is the absorbance at $663 \mathrm{~nm}$ and $\mathrm{A}_{645}$ is the absorbance at $645 \mathrm{~nm}$.

151 Total carotenoid $(\mathrm{mg} / \mathrm{g})=4 \times \mathrm{A}_{480} \times$ vol. of extraction / weight of the sample

152 where $\mathrm{A}_{480}$ is the optical density at $480 \mathrm{~nm}$ and 4 is the correction factor.

\section{Preparation of algal extracts and in vitro anti-cholesterol assay}

154

155

156

157

158

159

160

161

162

163

164

165

166

167

Algal extracts were prepared according to Hamouda et al., (2017). Different amounts of dried algal biomass $(50,100,150$ and $200 \mathrm{mg})$ were boiled in $10 \mathrm{~mL}$ distilled water for $30 \mathrm{~min}$, cooled and centrifuged at $1000 \mathrm{rpm}$ for $5 \mathrm{~min}$, after that the supernatants were taken as the algae extracts.

One hundred $\mu \mathrm{L}$ of each algae extracts was added to $100 \mu \mathrm{L}$ of cholesterol standard (The cholesterol $200 \mathrm{mg}$ was dissolved in $100 \mathrm{~mL}$ of phosphate buffer, $\mathrm{pH} 7.0$ and 1\% of Triton X100 surfactant), mixed and incubated for different periods $(15,30,45,60 \mathrm{~min})$ at $37^{\circ} \mathrm{C}$. The cholesterol concentration was measured using enzymatic colorimetric method according to Richmond, (1973), using cholesterol kit "Cholesterol - Liquizyme (Elitech - France)". The contents were incubated for $10 \mathrm{~min}$ at room temperature and the absorbance of sample and standard were read at wavelength $500 \mathrm{~nm}$ in a UV-Vis spectrophotometer against reagent blank. Anti-cholesterol activity of the extract was calculated using the following equation:

Inhibition $(\%)=$ Standard conc.-Sample conc. $/$ Standard conc. $\times 100$

\section{Extraction and determination of fatty acid composition}


One g of dry powder of $S$. platensis was extracted twice with $20 \mathrm{~mL}$ methanol $99.5 \%$, and

169

170

171

172

173

174

175

176

177

178

179

180

181

182

183

184

185

186

187

188 was stirred with magnetic stirrer for $15 \mathrm{~min}$; then the supernatant was collected by filtration. All supernatants were collected as a bold fraction and the solvent was evaporated using rotary evaporator. The methyl esters can be attained by transmethylation of the lipids by refluxing them for 90 min with methanol - benzene - sulfuric acid (20:10:1), respectively (Harborne, 1973 \& Mendham et al., 2000). The solution was concentrated to two thirds of its volume, water was then added for washing till free from acidity as indicating by litmus paper indicator, dried over anhydrous sodium sulfate and filtered, and the chemical composition was performed using Trace GC-ISQ Q mass spectrometer (Thermo Scientific, Austin, TX, USA) according to the method described by (El-Dougdoug, 2018).

\section{Feeding study}

\section{The animal model and experimental design}

Male Swiss Albino (SA) mice, 2 weeks old were purchased from VACSERA (Egyptian Company for Production of Vaccines, Giza, Egypt). The animals were housed in polycarbonate cages in a conditioned room at $20^{\circ} \mathrm{C} \pm 2$ with illumination for $12 \mathrm{~h}$. The initial body weight of the animals was approximately $30 \mathrm{~g}$. Weight gain was monitored and the $24 \mathrm{~h}$ food intake was recorded every 5 days. The duration of experimental treatment was five weeks. All animals were allowed to adapt to the environment for at least 10 days prior to dietary treatment. All the experimental procedures were carried out in accordance with international guidelines for care and use of laboratory animals and Ethics Committee of the Genetic Engineering \& Research Institute, Sadat City University, Egypt. (Approval number: gebri USC-009-1-19).

Peer) reviewing PDF | (2020:04:48239:1:4:NEW 22 Sep 2020) 
The animals were randomly divided into six groups and each group containing 8 mice;

190

191

192

193

194

195

196

197

198

199

200

201

202

203

204

205

206

207

208

209

210

two control groups and four treatment groups respectively according to Sangeetha et al., (2016)

with minor modifications.

Group I: negative control (was fed on the basic diet according to Reeves et al., (1993) plus 1\% saline (oral gavage)). Group II: was fed regular diet with $S$. platensis water extract in concentration of $15 \mathrm{mg} / \mathrm{mL}$ ( $1 \%$ of body weight) administration by oral gavage once daily for 5week period. Group III: positive control (was fed a high fat diet for 5-week period). Group IV: was fed a high-fat diet with $S$. platensis water extract in concentration of $15 \mathrm{mg} / \mathrm{mL}$ for 5 - week period. Group V: was fed a high-fat diet with $10 \mathrm{mg}$ standard atorvastatin for 5- week period.

Group VI: was fed a high-fat diet with $S$. platensis water extract in concentration of $7.5 \mathrm{mg} / \mathrm{mL}$ plus $5 \mathrm{mg}$ standard atorvastatin.

The composition of diets and animal groups is presented in Table 2. Body weights were measured at the end of the experimental period.

\section{Blood sampling from sacrificed mouse and serum analysis}

All the animals were euthanized using diethyl ether as an inhalant anaesthesia and blood samples were drawn from the heart of each sacrificed mouse. The blood samples were collected in test tubes for determination of biochemical analyses (serum lipid profile concentrations, liver enzymes activities, serum creatinine, and urea). The liver and heart were carefully dissected out, weighed and immediately preserved in $10 \%$ neutral buffered formalin. Blood serum was separated by centrifugation at $3000 \mathrm{rpm}$ for $15 \mathrm{~min}$ to obtain plasma, which was kept frozen at $20^{\circ} \mathrm{C}$ until analysis.

\section{i. lipid profile analysis}


212 triglycerides (TG) were determined according to Lopez et al., (1977) \& Fossati and Prencipe,

213 (1982), respectively. Low density lipoprotein (LDL) cholesterol was calculated according to

214 Warnick et al., (1990) as follows: LDL = TC - HDL - (TG/5).

215

216

217

218

219

220

221

222

223

224

225

226

227

228

229

230

231

232

\section{ii. Kidney functions}

The urea and creatinine concentrations were measured using colorimetric enzymatic method according to Kaplan and Glucose, (1984) \& Murray, (1984) respectively, by use of Diamond Diagnostics - Egypt kit.

\section{iii. Liver functions}

Aspartate aminotransferase (AST/SGOT) and alanine aminotransferase (ALT/SGPT) were measured using colorimetric enzymatic methods according to Reitman and Frankel, (1957) by use of Spinreact - Spain kit.

\section{Histopathological examination}

Liver and heart specimens were sliced, and pieces were preserved in $10 \%$ formalin for proper fixation. These tissues were processed and embedded in paraffin wax. Sections of 4-5 microns in thickness were cut and stained with hematoxylin and eosin. All the stained sections of the tissues were examined under microscope for circulatory disturbances, inflammation, degenerations, apoptosis, necrosis, and any other pathological changes, according to the method of (Suvarna et al., 2013).

\section{Statistical analyses}

All data were subjected to analysis of variance (ANOVA). Three replicates of each item were analyzed and the main values as well as the SD were given. Significance of the variable 
233 mean differences was determined using Duncan's multiple range tests $(\mathrm{p} \leq 0.05)$. All analyses

234 were carried out using SPSS 16 software (Sokal and Rohlf, 1995).

\section{RESULTS}

\section{Estimation of algal growth, chlorophyll a and carotenoid}

platensis in flasks with different colors (colorless, red, green and blue) on its cell dry weight, 239 chlorophyll a and total carotenoid contents.

flasks that was followed by (2.60 and 2.18) $\mathrm{g} / \mathrm{L}$ using the red and blue colored flasks, average of $2.00 \mathrm{~g} / \mathrm{L}$.

S. platensis cultivated in colorless flasks demonstrated the highest chlorophyll a content had the lowest chlorophyll a content $10.50 \mathrm{mg} / \mathrm{g}(1.05 \%)$. On the other hand, the highest contents

247 of carotenoid $61.88 \mathrm{mg} / \mathrm{g}(6.19 \%)$ was detected in dried cells of cultivated S. platensis in 248 colorless flasks, followed by $47.32 \mathrm{mg} / \mathrm{g}(4.73 \%)$ using the red-colored flasks and $39.68 \mathrm{mg} / \mathrm{g}$ $249(3.97 \%)$ using the blue-colored flasks, respectively. While the green-colored flasks, gave the lowest carotenoid content with an average of $36.40 \mathrm{mg} / \mathrm{g}(3.64 \%)$. There are variations in pigment content in all experimental trials, which may be associated with color of flasks. 
255 obtained from different colored glass flasks. An anti-cholesterol assay was performed and the

256 results revealed the potential activity of all extracts of algae in a dose-dependent manner.

Fig. 1A shows the percentages of the cholesterol reducing activity of water extract of $S$. platensis cultivated in colorless flasks as a control treatment. The highest cholesterol reduction percentage (76.01\%) was observed using the hot water extract of $S$. platensis at a concentration of $15 \mathrm{mg} / \mathrm{mL}$ after $60 \mathrm{~min}$ of incubation that was followed by $5 \mathrm{mg} / \mathrm{mL}$ (74.64\%) followed by 20 $\mathrm{mg} / \mathrm{mL}(72.27 \%)$ after incubation for time intervals of 60 and $30 \mathrm{~min}$, respectively. On the other hand, the concentration of $5 \mathrm{mg} / \mathrm{mL}$ gave the lowest cholesterol reduction percentage with an average of $61.85 \%$ value $(\mathrm{p}>0.05)$ after a period of $15 \mathrm{~min}$. No significant differences were observed between the treatments, furthermore the $S$. platensis concentration and incubation time had no significant effect on cholesterol-lowering levels. Fig. 1B illustrates the percentages of the cholesterol reduction of $S$. platensis obtained from blue flasks. No significant differences were observed between the treatments, moreover the $S$. platensis concentration and incubation time had no significant effect on cholesterol-lowering levels; and the reduction rate ranged between 45.5 to $48.4 \%$. Fig. 1C illustrates the percentages of the cholesterol reduction at different periods of time and different concentrations of dry weight of $S$. platensis obtained from green flasks. The highest cholesterol reduction percentage $(52.8 \%)$ was observed using the hot-water extract of $S$. platensis at a concentration of $15 \mathrm{mg} / \mathrm{mL}$ after $60 \mathrm{~min}$ of incubation; on the other hand, the concentration of $20 \mathrm{mg} / \mathrm{mL}$ gave the lowest cholesterol reduction percentage with an average of $40.9 \%$ value $(\mathrm{p}<0.05)$ after a period of $15 \mathrm{~min}$. No significant differences were observed between the treatments, furthermore the $S$. platensis concentration and incubation time had no significant effect on cholesterol-lowering levels. In the case of red flasks (Fig. 1D), the highest cholesterol 
277 reduction percentage $(52.9 \%)$ was observed using the hot-water extract of S. platensis at a

278 concentration of $20 \mathrm{mg} / \mathrm{mL}$ after $60 \mathrm{~min}$ of incubation.

279 GC-MS analysis of Spirulina platensis

280 Methanolic extract of $S$. platensis cultivated in colorless flasks was analyzed by gas

281 chromatography-mass spectrometry (GC-MS) for determining of its volatile components based

282 on their retention time and peak area (Table 4 and Fig. 2). The GC-MS analysis showed 15

283 bioactive compounds were identified and grouped according to their chemical structures. The

284 major volatile components contained were isochiapin B (3.81\%), oxiraneundecanoic acid, 3-

285 pentyl (2.32\%), dimethoxy glycerol docosyl ether (2.1\%), 9 hexadecenoic acid, eicosyl ester

286 (1.69\%), hexamethylcyclotrisiloxane (1.23\%), 9-octadecenoic acid (Z)-, phenylmethyl ester

287 (0.69), oleic safflower oil (0.66\%), palmitic acid (0.51\%), 10,13-octadecadiynoic acid (0.56\%),

288 9-octadecenoic acid, (2-phenyl-1,3-dioxolan-4-yl) methyl ester, cis- (0.46\%), 7,10-

289 pentadecadiynoic acid $(0.44 \%)$, propanedioic acid dimethyl ester $(0.31 \%)$, palmitic acid (2290 phenyl-1,3-dioxolan-4-yl) $(0.35 \%)$.

The presence of antioxidant compounds such as mono and polyunsaturated fatty acids in

292

293

294

295

296

297

298 the microalgae Spirulina can be the cause of the distinguishing characteristics of Spirulina on the reduce of serum lipid levels. The GC-MS analysis of the S. platensis methanolic extract shows fatty acids that have also been reported to have some anti-cholesteremic activity, especially eicosenoic acid and high-oleic safflower oil (sunflower oil is mainly triglycerides, typically derived from the fatty acids linoleic acid "poly-unsaturated omega-6" and oleic acid" monounsaturated omega-9" with differing concentrations). Hexadecanoic acid (palmitic acid) ethyl ester, exists naturally in butter, cheese, milk, and meat, as well as cocoa butter, soybean oil, and 
299 sunflower oil; also sodium palmitate is authorized as a natural additive in organic products (US

300 Soil Association standard 50.5.3).

301 Evaluation of body weight and lipid profile

302 The body weights of mice that received S. platensis water extracts are listed in Table 5. It

303 showed that the mice fed on high fats diet increased in weight after five weeks of treatment and

304 the mice injected with $(15 \mathrm{mg} / \mathrm{mL})$ oral gavage with $S$. platensis only decreased in weight from $30529.0 \mathrm{~g}$ at the beginning of experiment to $24.7 \mathrm{~g}$ by $14.9 \%$.

306 The mice fed on high fat diet with the same concentration of S. platensis decreased from

$30731.0 \mathrm{~g}$ at the beginning to $23.7 \mathrm{~g}$ at the end of the experiment by $23.7 \%$, while the mice fed on

308 high fat diet with $S$. platensis in concentration of $7.5 \mathrm{mg} / \mathrm{mL}+$ atorvastatin $(5 \mathrm{mg} / \mathrm{kg}$ body 309 weight) decreased from $28.0 \mathrm{~g}$ at the beginning to $23.5 \mathrm{~g}$ at the end of the experiment by $16.1 \%$.

310 Fig. 3 showed that mice fed on high fat diets showed significant increase $(P<0.05)$ in

311 total cholesterol (TC), triglycerides (TG) and low density lipoproteins (LDL) and significant 312 decrease $(P<0.05)$ in high density lipoproteins (HDL) compared to those fed on normal diet. 313 After five weeks of mice treatment with $S$. platensis only, serum TC, TG and LDL levels were 314 reduced significantly $(P<0.05)$, while HDL showed significant increase $(P<0.05)$ as compared to 315 before treatment.

316 Hypercholesterolemic mice treated with $S$. platensis $(7.5 \mathrm{mg} / \mathrm{mL})+$ atorvastatin $(5$

$317 \mathrm{mg} / \mathrm{kg})$ showed significant decrease $(P<0.05)$ in serum TC, TG and LDL levels $(89.9,59.4$ and $31822.5 \mathrm{mg} / \mathrm{dL}$, respectively) and significant increase in the HDL cholesterol level $55.5 \mathrm{mg} / \mathrm{dL}$ $319(P<0.05)$ compare with control. Also it is clear that the HDL contents were greater in all 320 treatments of $S$. platensis groups especially $S$. platensis only group since it reached $58.8 \mathrm{mg} / \mathrm{dL}$.

\section{Evaluation of liver and kidney functions}


Fig. 4 showed that mice fed on high fat diets showed significant increase $(P<0.05)$ in aspartate aminotransferase (AST) and alanine aminotransferase (ALT) liver enzymes (108.4, 85.5 U/L, respectively) compared to animals fed on normal diet and S. platensis diet only (92.0,

79.2 U/L, respectively). On the other hand liver enzymes significant decreased $(P<0.05)$ in hypercholesterolemic mice which treated with $S$. platensis only or in combination with atorvastatin.

Toxic renal effects are normally manifested with increases in the level of serum urea.

The recorded values of renal parameters (urea and creatinine) indicate significant reduction, for

level of renal values, while groups IV, V and VI showed reduction in the level of renal values.

On the other hand, groups I and II were considered normal cases.

333

334

335

336

337

338

339

340

341

342

343

344

\section{Histological study}

Normal saline (negative control, group I): liver showed normal hepatic parenchyma with preserved lobules, cords, sinusoids, bile canaliculi, portal area and stromal structures. The kupffer cells were prominent. Heart sections revealed normal cardiomyocytes with a few hyaline degeneration in some of them (Fig.6). S. platensis only (group II): liver showed normal hepatic parenchyma with preserved lobules, cords, sinusoids, bile canaliculi, portal area and stromal structures with prominent kupffur cells. Heart sections revealed mild interstitial edema and myocardial degeneration (Fig.7). The mice fed on high fat diets (positive control, group III): liver sections showed wide spread centrolobular and periportal micro and macrosteatosis beside portal round cells aggregation. Heart sections revealed mild congestion of the coronary blood vessels and intermuscular capillaries. Moderate number of cardiomyocytes showed macrosteatosis. Interstitial edema was also seen (Fig.8). The mice fed on high fat diets with $S$. 
345 platensis (group IV): liver sections showed wide spread centrolobular and periportal micro and

346 macro steatosis. Mild portal round cells aggregations and prominent kupffer cells were observed.

347 Heart: showed mild congestion of the coronary blood vessels and intermuscular capillaries. Mild

348 to moderate number of cardiomyocytes showed macrosteatosis. Interstitial edema was also seen

349 (Fig.9). The mice fed on high fat diets with atrovastin $10 \mathrm{mg} / \mathrm{kg}$ instead of S. platensis (group

$350 \mathrm{~V})$ : liver sections showed congestion of hepatic blood vessels with perivascular leukocytic

351 infiltration mainly neutrophils in addition to extravasated erythrocytes. Examined sections from

352 the heart showed sever congestion of coronary blood vessels, interstitial edema beside steatosis

353 and hyaline degeneration of some cardiomyocytes (Fig.10). The mice fed on high fat diets with

354 atrovastin $5 \mathrm{mg} / \mathrm{kg}$ and $S$. platensis $7.5 \mathrm{mg} / \mathrm{kg}$ (group VI): liver sections revealed apparently

355 normal hepatic parenchyma with preserved lobules, cords and sinusoids beside presence some

356 dispersed apoptotic and de-generated cells. Heart sections revealed normal cardiomyocytes with

357 mild interstitial edema and hyaline degeneration in some cells (Fig.11).

\section{DISCUSSION}

Increased pigment concentration (chlorophyll a content and total carotenoid) was closely

related to cell dry weight of $S$. platensis. Chlorophyll is one of the precious bioactive compounds that can be obtained from microalgae biomass. Chlorophyll is used as antioxidant, natural food coloring agent and has anti-mutagenic properties (Priyadarshani and Rath, 2012). Carotenoids are used in feed and food as flavorings and colorants and in nutritional supplements as a source of pro-vitamin A (Kim, 2015). There is confirmation that these pigments may protect humans

365 from dangerous disorders related with oxidative and inflammatory stress involving skin 366 degeneration, cardiovascular disease, aging, certain types of cancer, and age-related diseases of 367 the eye (Rao and Rao, 2007). 
platensis cells. Habib et al., (2008) introduced average irradiance and specific light energy

and Duerr, (1990) found that Spirulina can respond to changes in the spectral distribution of and blue light best, so algae whose cells contain high concentration of chlorophyll if are

cultivated in red and blue flasks, grow well and tend to produce a large amount of biomass; compared to those under green flask conditions. In this case, the photoreceptor called cryptochrome (a sensor of blue irradiance and blue/green ratio) might be responsible for inhibition (Sellaro et al., 2010).

Olaizola and Duerr, (1990) concluded that the growth rate of S. platensis increased rapidly under white and red lights, while under blue light the growth rate obtained lower; Also, Vo et al., (2017) reported that the red and white light conditions induced the growth and biosynthesis organic constituents for instance carotenoid.

From the above results we could consider S. platensis in oceans and in open area to be very useful mass as a dry weight, so the effect of light so important; not cancellation the light or making a barrier between light and the microorganisms. Colla et al., (2008) affirmed that the presence of antioxidant compounds such as phenolic acids, a-tocopherol and b-carotene presents in Spirulina extracts were responsible for the antioxidant activity and can be the cause of the properties of Spirulina on the decrease of serum lipid levels. Nagaoka et al., (2005) found that both, S. platensis concentrate (SPC) and C-phycocyanin (a proteic pigment extracted of Spirulina) caused hypocholesterolemic effect in rats; also, proposed that the hypocholesterolemic 390 mechanism of SPC may involve the inhibition of both jejunal cholesterol absorption and ileal 
391 bile acid reabsorption, furthermore C-phycocyanin might be the active ingredient in Spirulina

392 responsible for the hypolipidemic activity than SPC. Oleic acid linoleic and palmitic acids were

393 found in methanolic extracts of Spirulina. Oleic acid is associated with several health benefits,

394 which mainly include anti-cancer activity and prevention of cardiovascular disease, platelet

395 aggregation and hypertension (de Souza et al., 2015). Singh and Nimbkar, (2016) testified that

396 an eight gram daily dose of safflower oil for 16 weeks can enhance health measures such as

397 glycaemia, inflammation, and blood lipids in obese, postmenopausal women who have diabetes

398 type 2. Our results agree with those reported by Gheda et al., (2013) who found that the higher

399 percentage of linoleic and palmitic acids were found in methanolic extracts of Spirulina

400 compared to crude Spirulina. These results open our minds for the natural medications to

401 diminish weight and decrease cholesterol level within few weeks. Similar finding was obtained

402 by Zhao et al., (2019) who stated that S. platensis protein (SPP) and protein hydrolysate (SPPH)

403 possessed anti-obesity effect in mice and total cholesterol reduction activities by modulating the

404 expressions of various key genes related with lipid metabolism in brain and liver, for instance

405 Acadm, Retn, Fabp4, Ppard, Slc27a1, etc. The main metabolic pathways for reducing cholesterol

406 are via conversion to bile acids or preventing the cholesterol synthesis by inhibiting the HMG

407 CoA reductase enzyme; Ama Moor et al., (2017) found that S. platensis may reveal

408 hypolipidemic activity through the activation of lecithine cholesterol acyl transferase LCAT, also

409 confirmed that the administration of $S$. platensis inhibits the plasmatic activity of HMG COA

410 reductase significantly in rats. Belay, (2002) also stated that administration of Arthrospira

411 maxima associated with simvastatin prevents the acute fatty liver primary approach for

412 controlling de novo cholesterol synthesis. Torres et al., (2007) concluded that S. maxima had

413 hypolipemic effects, especially on the TG and the LDL-C concentrations, but indirectly on TC 
414 and HDL-C values, and positive effects on reducing systolic and diastolic blood pressure by

415 enhancing nitrous oxide release. Colla, (2008) found that the serum levels of HDL were higher

416 in the groups fed with Spirulina, and emphasized the importance of Spirulina biomass reducing

417 the serum levels of total cholesterol and increasing the serum levels of HDL-cholesterol.

\section{CONCLUSIONS}

Artificial light provides better regulation of intensity, duration, and light spectra and light characteristics have a profound influence on microalgae metabolism and development. The present study provides a new insight for production of blue-green algae $S$. platensis biomass in different colored flasks under artificial illumination, also the anti-hypercholesterolemic potential of aqueous extract of $S$. platensis in vitro and in the diet induced hypercholesterolemic Swiss albino mice. S. platensis developed in colorless flasks under continuous illumination using cool white fluorescent with the intensity of photosynthetically light was 2500 lux $\left(35 \mu \mathrm{mol} \mathrm{m}^{-2} \mathrm{~s}^{-1}\right)$ demonstrated the highest chlorophyll a and carotenoid contents based on dry weight, furthermore administration of hot aqueous extract of $S$. platensis which obtained from the same kind of flasks resulted in vitro and in vivo hypolipidemic effects. The highest cholesterol reduction percentage in vitro $(76.01 \%)$ was observed using the hot aqueous extract of $S$. platensis at a concentration of $15 \mathrm{mg} / \mathrm{mL}$ after $60 \mathrm{~min}$ of incubation; also clearly showed that extract produced from S. platensis reduced serum TC, TG and LDL; furthermore, it increased serum HDL levels and possessed anti-obesity effect in animal model.

434 great potential as possible therapy for reducing cholesterol levels. This product exerted a 435 significant hypocholesterolemic effect on Swiss albino mice fed with a high cholesterol diet. $S$. 436 platensis consumption as a dietary supplement might be useful in reducing total cholesterol and 
437 TG levels in the serum and liver for humans. Hot aqueous extract of S. platensis appears to be

438 safe for its potential use in hypercholesterolemia control.

439 Scope for future work

440 Microalgae are among the fastest growing photosynthetic organisms giving a higher yield

441 than other crops they have unique properties of $\mathrm{CO}_{2}$ fixation and release of oxygen. The research

442 findings and trials of this paper can be a fillip for further research on production of low cost

443 Spirulina with superior quality via optimizing physical and chemical conditions of production

444 medium; moreover further clinical studies are needed for confirming some pharmaceutical

445 properties such as anti-diabetic and cancer activities.

446 Conflict of interest

447 The authors declared that there is no conflict of interests.

448 Funding

449 The author(s) received no financial support for the research, authorship, and/or publication of

450 this article.

451 Ethical statements

452 The manuscript does not contain experiments using human study.

453

454

455

456

457

458

459

460

461

462

463

464

465

466

467

468

469

470

\section{REFERENCES}

Abed RM, Dobretsov S, Sudesh K. 2009. Applications of cyanobacteria in biotechnology. Journal of applied microbiology 106:1-12 doi:10.1111/j.1365-2672.2008.03918.x

\section{Ama Moor VJ, Nya Biapa PC, Nono Njinkio BL, Moukette BM, Sando Z, Kenfack}

C, Ateba B, Matip MEN, Pieme CA, Ngogang J. 2017. Hypolipidemic effect and activation of Lecithin Cholesterol Acyl Transferase (LCAT) by aqueous extract of Spirulina platensis during toxicological investigation. BMC Nutrition 3, 25

DOI: https://doi.org/10.1186/s40795-017-0146-2

Barufi JB, Figueroa F, Plastino E. 2015. Effects of light quality on reproduction, growth and pigment content of Gracilaria birdiae (Rhodophyta: Gracilariales). Scientia Marina 79:15-24

Belay A. 1997. "Mass Culture of Spirulina Outdoors: The Earthrise Farms Experience," In: A. Vonshak, Ed., Spirulina platensis (Arthrospira), Physiology, Cell Biology and Biotechnology, Taylor \& Francis, London, pp. 131-158 
471

472

473

474

475

476

477

478

479

480

481

482

483

484

485

486

487

488

489

490

491

492

493

494

495

496

497

498

499

500

501

502

503

504

505

506

507

508

509

510

511

512

513

514

515

516
Belay A. 2002. The Potential Application of Spirulina (Arthrospira) as a Nutritional Health and Therapeutic Supplement in Health Management. Journal of the American Nutraceutical Association 5:27-48

Colla LM, Muccillo-Baisch AL, Costa JAV. 2008. Spirulina platensis effects on the levels of total cholesterol, HDL cholesterol and triglycerides in rabbits fed with a hypercholesterolemic diet. Brazilian Archives of Biology and Technology 51(2):405-411

http://dx.doi.org/10.1590/ S1516-89132008000200022

de Souza RJ, Mente A, Maroleanu A, Cozma AI, Ha V, Kishibe T, Uleryk E, Budylowski P, Schünemann H, Beyene J, Anand SS. 2015. Intake of saturated and trans unsaturated fatty acids and risk of all cause mortality, cardiovascular disease, and type 2 diabetes: systematic review and meta-analysis of observational studies. BMJ (Clinical research ed.) 351, h3978 https://doi.org/10.1136/bmj.h3978

El-Dougdoug KA, Sofy AR, Mousa AA, Sofy MR, Hmed AA, Abbas AA. 2018. Safe and Efficacious Anti-Cytomegalovirus Agents with Therapeutic Activity in vitro. Journal of Microbiology Research 8(2)33-42 doi: 10.5923/j.microbiology.20180802.02.

Fossati P, Prencipe L. 1982. Serum triglycerides determined colorimetrically with an enzyme that produces hydrogen peroxide. Clinical chemistry 28(10):2077-2080

Gantar M, Svirčev Z. 2008. MICROALGAE AND CYANOBACTERIA: FOOD FOR THOUGHT(1). Journal of phycology 44(2):260-268

https://doi.org/10.1111/j.1529-8817.2008.00469.x

Gheda SF, Khalil M, Gheida S. 2013. In vitro and in vivo preliminary results on Spirulina platensis for treatment of impetigo: Topical cream application. African Journal of Biotechnology 12

González de Rivera C, Miranda-Zamora R, Díaz-Zagoya JC, Juárez-Oropeza MA. 1993. Preventive effect of Spirulina maxima on the fatty liver induced by a fructose-rich diet in the rat, a preliminary report. Life sciences 53(1): 57-61

https://doi.org/10.1016/0024-3205(93)90611-6

Gutiérrez-Salmeán G, Fabila-Castillo L, Chamorro-Cevallos G. 2015. NUTRITIONAL AND TOXICOLOGICAL ASPECTS OF SPIRULINA (ARTHROSPIRA). Nutricion hospitalaria 32(1):34-40

https://doi.org/10.3305/nh.2015.32.1.9001

Habib MAB, Parvin M, Huntington TC, Hasan MR. 2008. A review on culture, production and use of spirulina as food for humans and feeds for domestic animals and fish. FAO Fisheries and Aquaculture Circular. No. 1034. Rome, FAO. 33p 
517 Hamouda RA, Al-Saman MA, El-Sabbagh SM, Abo El-Seoud GW, Hendawy AN. 2017.

518 Approach to improve the productivity of bioactive compounds of the cyanobacterium Anabaena 519 oryzae using factorial design. Egyptian Journal of Basic and Applied Sciences 4(3):190-195

520 DOI: $10.1016 / j$.ejbas.2017.06.003

521 Hamouda RA, Sorour NM, Yehheia DS. 2016. Biodegradation of crude oil by Anabaena

522 oryzae, Chlorella kessleri and its consortium under mixotrophic conditions. International

523 Biodeterioration and Biodegredation 112:128-134

524

525

526

527

528

529

530

531

532

533

534

Harborne JB. 1973. Phytochemical Methods. Chapman and Hall Ltd., London, 49-188. ISBN13: 978-0-412-23050-9

DOl: $10.1007 / 978-94-009-5921-7$

Jeffrey SW, Humphrey GF. 1975. New spectrophotometric equations for determining chlorophylls $\mathrm{a}, \mathrm{b}, \mathrm{c}_{1}$ and $\mathrm{c}_{2}$ in higher plants, algae and natural phytoplankon. Biochemie und Physiolgie der Pflanzen 167(2):191-194

Kaewpintong K, Shotipruk A, Powtongsook S, Pavasant P. 2007. Photoautotrophic high-density cultivation of vegetative cells of Haematococcus pluvialis in airlift bioreactor.

535 Bioresource Technology 98:288-295

536 https://doi.org/10.1016/j.biortech.2006.01.011

537

538

539

Kaplan A, Glucose K. 1984. ClinChem. The CV Mosby Co., St Louis, Toronto, Princeton, 436 p.

540

541

542

543

544

545

546

547

548

Kim HM, Lee EH, Cho HH, Moon YH. 1998. Inhibitory effect of mast cell-mediated immediate type allergic reactions in rats by spirulina. Biochemical pharmacology 55(7):10711076

https://doi.org/10.1016/s0006-2952(97)00678-3

Kim SK. 2015. Handbook of Marine Microalgae: Biotechnology Advances. Academic Press ISBN: 9780128011249

Lecerf JM, de Lorgeril M. 2011. Dietary cholesterol: from physiology to cardiovascular risk. British Journal of Nutrition 106(1):6-14 https://doi.org/10.1017/S0007114511000237

552

Lopes -Virella MF, Stone P, Ellis S, Colwell JA. 1977. Cholesterol determination in highdensity lipoproteins separated by three different methods. Clinical chemistry 23(5):882-884

Mendham J, Denney RC, Barnes JD, Thomas MJK. 2000. Vogel's Quantitative Chemical

557

558

559 Analysis. $6^{\text {th }}$ Edition. Prentice Hall. ISBN-10:0582226287

560

Michael DR, Moss JWE, Calvente DL, Garaiova I, Plummer SF, Ramji DP. 2016.

561 Lactobacillus plantarum CUL66 can impact cholesterol homeostasis in Caco-2 enterocytes. Beneficial Microbes 7:443-451

562

DOI: $10.3920 / \mathrm{bm} 2015.0146$ 
563

564

565

566

567

568

569

570

571

572

573

574

575

576

577

578

579

580

581

582

583

584

585

586

587

588

589

590

591

592

593

594

595

596

597

598

599

600

601

602

603

604

605

606

Murray RL. 1984. Creatinine In: Clinical Chemistry; Theory, Analysis and Correlation, Kaplan LA and AJ Pesce (Eds.). CV Mosby Co., St. Louis, pp:1247-1253

Nagaoka S, Shimizu K, Kaneko H, Shibayama F, Morikawa K, Kanamaru Y, Otsuka A, Hirahashi T, Kato T. 2005. A novel protein C phycocyanin plays a crucial role in the hypocholesterolemic action of Spirulina platensis concentrate in rats: Journal of Nutrition 135(10):2425-2430 https://doi.org/10.1093/jn/135.10.2425

Nascimento MM, Pecoits-Filho R, Lindholm B, Riella MC, Stenvinkel P. 2002.

Inflammation, malnutrition and atherosclerosisin end-stage renal disease: a global perspective. Blood Purification 20:454-458

https://doi.org/10.1159/000063559

Nigam VK, Verma R, Kumar A, Kundu S, Ghosh P. 2007. Influence of medium constituents on the biosynthesis of cephalosporin-C. Electronic Journal of Biotechnology 10(2)

DOI: $10.2225 /$ vol10-issue2-fulltext-8

Olaizola M, Duerr EO. 1990. Effects of light intensity and quality on the growth rate and photosynthetic pigment content of Spirulina platensis. Journal of Applied Phycology 2:97-104

Ponce-Canchihuamán JC, Perez-Mendez O, Hernández-Muñoz R, Torres-Durán PV, Juárez- Oropeza MA. 2010. Protective effects of Spirulina maxima on hyperlipidemia and oxidative-stress inducedby lead acetate in the liver and kidney. Lipids in health and disease 9:35 https://doi.org/10.1186/1476-511X-9-35

Priyadarshani I, Rath B. 2012. Bioactive compounds from microalgae and cyanobacteria: utility and applications. International Journal of Pharmaceutical Sciences and Research 3(10):4123-4130

Rao AV, Rao LG. 2007. Carotenoids and human health. Pharmacological research 55:207-216 https://doi.org/10.1016/j.phrs.2007.01.012

Reeves PG, Roossow KL, Lindlauf J. 1993. Development and testing of the AIN-93 purified diets for rodents: Results on growth, kidney calcification and bone mineralization in rats and mice. The Journal of nutrition 123(11):1923-1931

https://doi.org/10.1093/jn/123.11.1923

Reitman S, Frankel S. 1957. A colorimetric method for the determination of serum glutamic oxalacetic and glutamic pyruvic transaminases. American journal of clinical pathology 28(1):5663

https://doi.org/10.1093/ajcp/28.1.56 
607 Richmond W. 1973. Preparation and properties of a cholesterol oxidase from Nocardia sp. and 608 its application to the enzymatic assay of total cholesterol in serum. Clinical Chemistry

609 19(12):1350-1356

610 https://doi.org/10.1093/clinchem/19.12.1350

611

Ridley SM. 1977. Interaction of chloroplasts with inhibitors: induction of chlorosis by diuron during prolonged illumination in vitro. Plant Physiology 59(4):724-732

https://doi.org/10.1104/pp.59.4.724

Samson R, Leduy A. 1985. Multistage continuous cultivation of blue green alga Spirulina maxima in the flat tank photobioreactors with recycle. The Canadian Journal of Chemical Engineering 63(1):105-112

https://doi.org/10.1002/cjce.5450630117

Sánchez Mirón A, Cerón García MC, García Camacho F, Molina Grima E, Chisti Y. 2002. Growth and biochemical characterization of microalgal biomass produced in bubble column and airlift photobioreactors: studies in fed-batch culture. Enzyme and Microbial Technology 31:

1015-1023

Sangeetha, Patel DS, Pandanaboina CS. 2016. Hepato-Protective Effects of Blue-Green Alga Spirulina platensis on Diclofenac-Induced Liver Injury in Rats. Malaysian Journal of Nutrition 22(2):289-299

\section{Sellaro R, Crepy M, Trupkin SA, Karayekov E, Buchovsky AS, Rossi C, Casal JJ. 2010.} Cryptochrome as a sensor of the blue/green ratio of natural radiation in Arabidopsis. Plant Physiology 154(1):401-409

DOI: $10.1104 / \mathrm{pp} .110 .160820$

Sharmila D, Suresh A, Indhumathi J, Gowtham K, Velmurugan N. 2018. Impact of various color filtered LED lights on microalgae growth, pigments and lipid production. European Journal of Biotechnology and Bioscience 6(6):1-7

Singh V, Nimbkar N. 2016. Breeding Oilseed Crops for Sustainable Production, Opportunities and Constraints, Chapter 7 - Safflower. Academic Press 149-167

Sokal RR, Rohlf FJ. 1995. Biometry: The Principles and Practice of Statistics in Biological Research, $3^{\text {rd }}$ edition. W. H. Freeman, New York

Soliman GA. 2018. Dietary Cholesterol and the Lack of Evidence in Cardiovascular Disease. Nutrients 10(6) 780

https://doi.org/10.3390/nu10060780

Soni RA, Sudhakar K, Rana RS. 2017. Spirulina - From growth to nutritional product: A review. Trends in Food Science \& Technology, 69:157-171

DOI: 10.1016/j.tifs.2017.09.010

652 
653 Suvarna KS, Layton C, Bancroft JD. 2013. Bancroft's Theory and Practice of Histological

654 Techniques, $7^{\text {th }}$ Edition. Churchill Livingstone. ISBN-10: 9780702042263

655

656

657

658

659

660

661

662

663

664

665

666

667

668

669

670

671

672

673

674

675

676

677

678

679

680

681

682

683

684

685

686

Tabas I. 2002. Cholesterol in health and disease. The Journal of clinical investigation 110(5): 583-590 https://doi.org/10.1172/JCI16381

Torres-Duran PV, Ferreira-Hermosillo A, Juarez-Oropeza MA. 2007. Antihyperlipemic and antihypertensive effects of Spirulina maxima in an open sample of Mexican population: a preliminary report. Lipids in health and disease 6, 33 doi:10.1186/1476-511X-6-33

Vardaka E, Kormas KA, Katsiapi M, Genitsaris S, Moustaka-Gouni M. 2016. Molecular diversity of bacteria in commercially available "Spirulina" food supplements. Peer J, 4, e1610 https://doi.org/10.7717/peerj.1610

Vo T, Nguyen NA, Huynh PT, Nguyen H, Nim T, Tran DV, Nguyen PH. 2017. The growth and lipid accumulation of Spirulina sp. under different light conditions. World Journal of Food Science and Technology 1(3):101-104 doi: $10.11648 /$ j.wjfst.20170103.13

Ward NC, Watts GF, Eckel RH. 2019. Statin Toxicity: Mechanistic Insights and Clinical Implications. Circulation Research 328-350

DOI: 10.1161/CIRCRESAHA.118.312782

Warnick GR, Knopp RH, Fitzpatrick V, Branson L. 1990. Estimating low-density lipoprotein cholesterol by the Friedewald equation is adequate for classifying patients on the basis of nationally recommended cutpoints. Clinical Chemistry 36(1):15-19

William WC. 2003. Lipid analysis: isolation, separation, identification, and structural analysis of lipid. The oily press. $3^{\text {rd }}$ edition. ISBN 0-9531949-5-7

Yang HN, Lee EH, Kim HM. 1997. Spirulina platensis inhibits anaphylactic reaction. Life sciences $61: 1237-1244$

687 https://doi.org/10.1016/s0024-3205(97)00668-1

688

689

690

Zarrouk C. 1966. Contribution a létuded'unecyanobacterie: influence de divers facteurs

691

692

693

694

695 physiques et chimiques sur la croissance et la photosynthése de Spirulina maxima (Setch et Gardner) Geitler. Ph.D. thesis, University of Paris, France

Zeng WL, Li HR, Cai ZL, Ouyang F. 2001. The relationship between Spirulina platensis Geitler growth and its light utilization. Journal of Plant Resources and Environment 10:7-10

Zeng XH, Danquah, MK, Chen, XD, Lu YH. 2011. Microalgae bioengineering: Autotrophic 698 15(6):3252-3260 
700 Zhao B, Cui Y, Fan X, Qi P, Liu C, Zhou X, Zhang X. 2019. Anti-obesity effects of Spirulina

701 platensis protein hydrolysate by modulating brain liver axis in high-fat diet fed mice. PLoS ONE 702 14(6): e0218543

703 https://doi.org/10.1371/journal.pone.0218543

704 


\section{Figure 1}

The effect aqueous extracts of $S$. platensis

The effect aqueous extracts of $S$. platensis $(\mathrm{mg} / \mathrm{mL})$ obtained from colored flasks on total cholesterol; A, control; B, blue; C, green; D, red; the different super script letters in the same column group are significantly different $(p<0.05)$ 


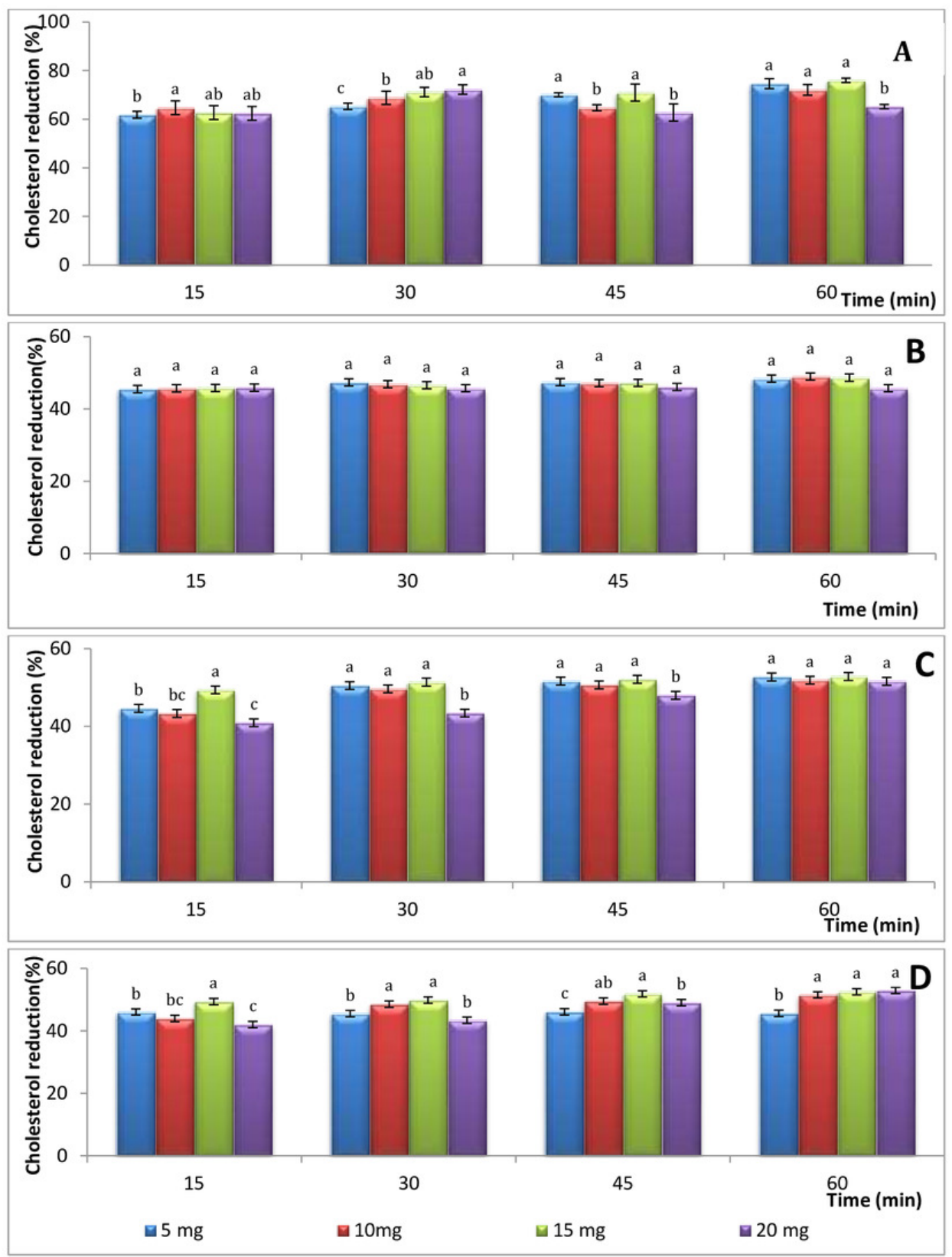


Figure 2

Gas chromatography

Gas chromatography and mass spectrometry spectrum of methanolic extract of S. platensis (TIC: total ion chromatogram) 


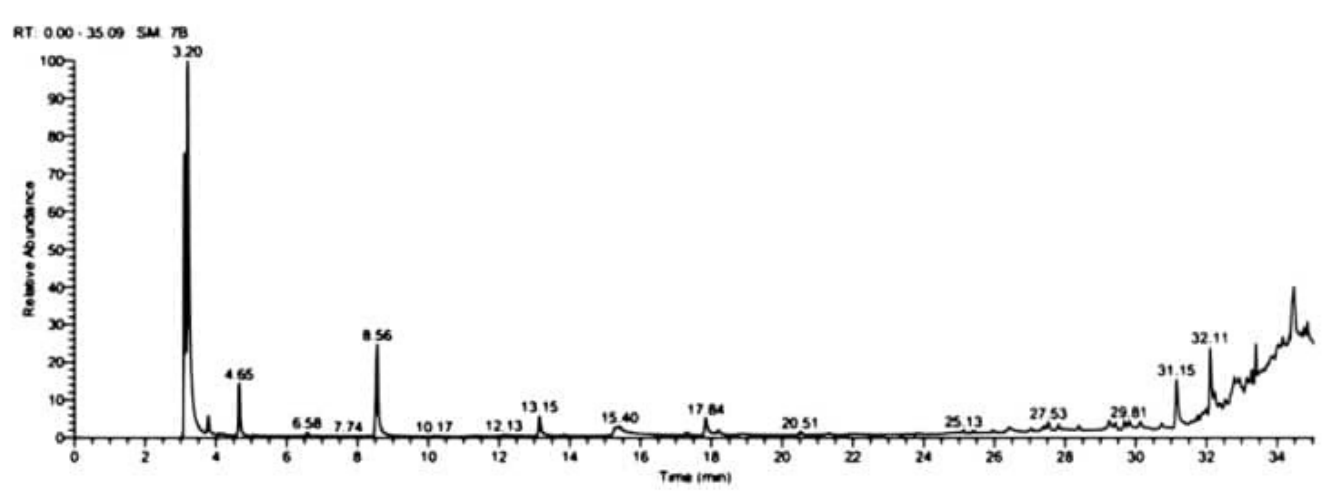


Figure 3

Effect of different S. platensis formulations on plasma cholesterol

Effect of different S. platensis formulations on plasma cholesterol, triglycerides, cholesterolhigh density lipoprotein (HDL) and cholesterol-low density lipoprotein (LDL) in mice after 5 weeks 


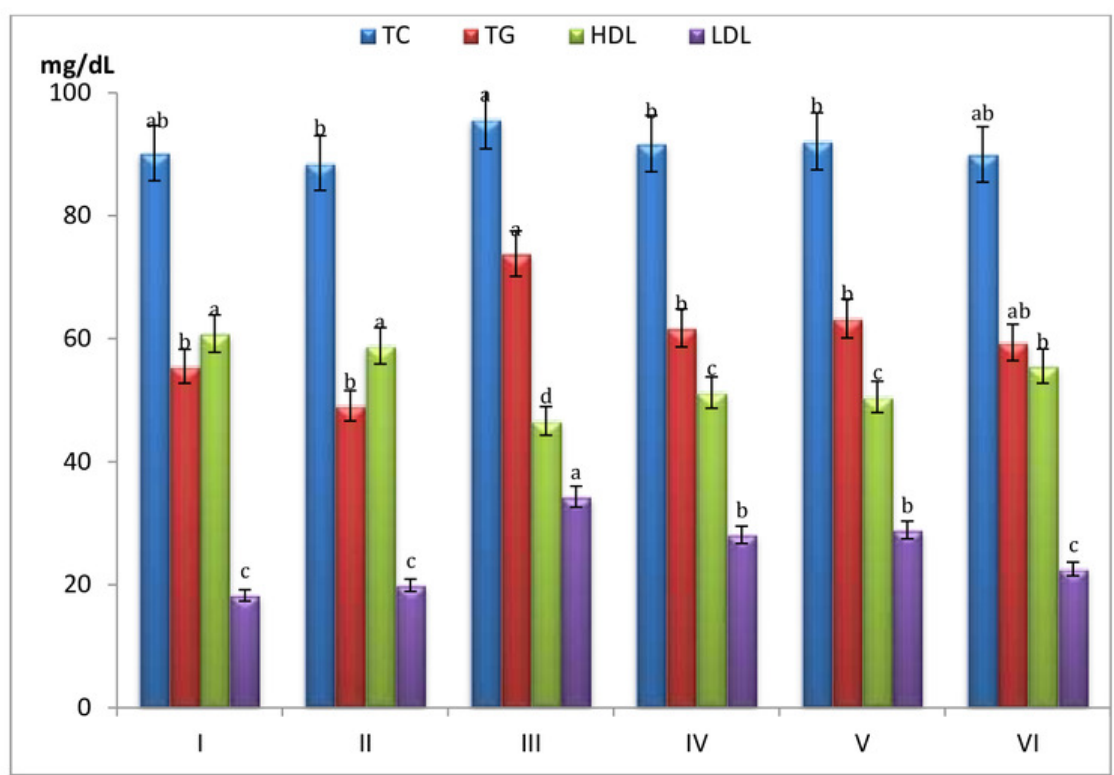


Figure 4

Effect of different S. platensis formulations on liver enzymes

Effect of different S. platensis formulations on liver enzymes; aspartate aminotransferase (AST) and alanine aminotransferase (ALT) in mice after 5 weeks 


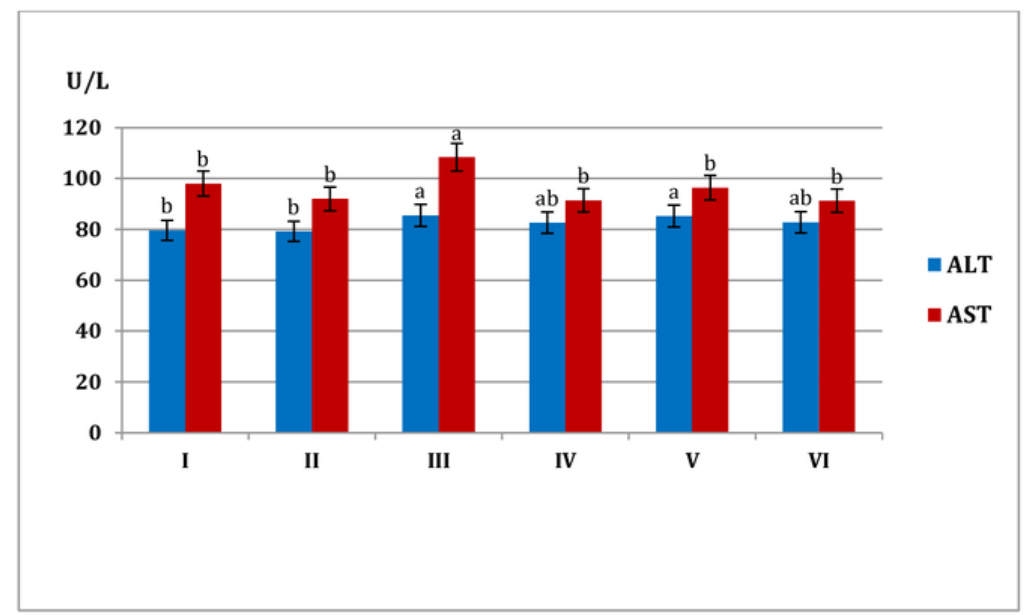


Figure 5

Effect of different S. platensis formulations on kidney functions; urea (A) and creatinine (B) in mice after 5 weeks

Effect of different S. platensis formulations on kidney functions; urea (A) and creatinine (B) in mice after 5 weeks 

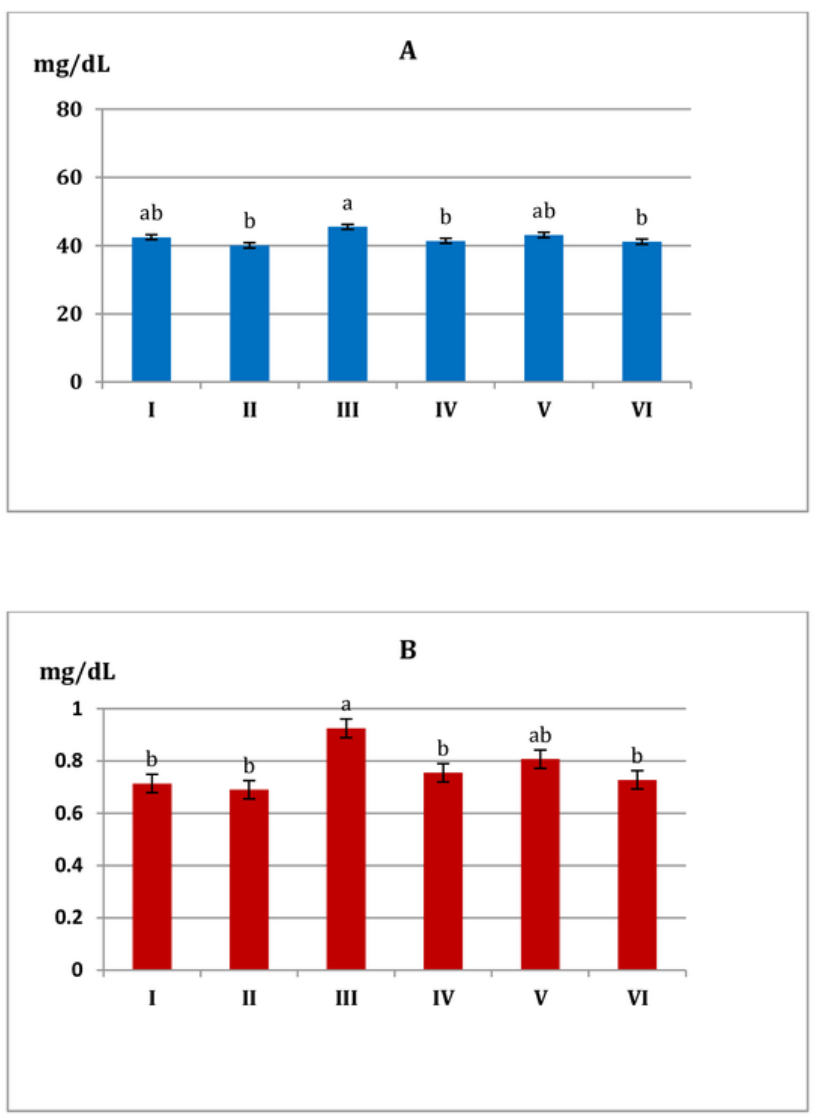


\section{Figure 6}

Photomicrograph of liver sections $(A \& B)$ showing normal hepatic parenchyma with preserved hepatic cords, sinusoids and prominent kupffur cells (curved arrows). Heart sections $(C \& D)$ showing normal cardiomyocytes with hyaline degeneration in some cells

Photomicrograph of liver sections (A \& B) showing normal hepatic parenchyma with preserved hepatic cords, sinusoids and prominent kupffur cells (curved arrows). Heart sections $(C \& D)$ showing normal cardiomyocytes with hyaline degeneration in some cells 


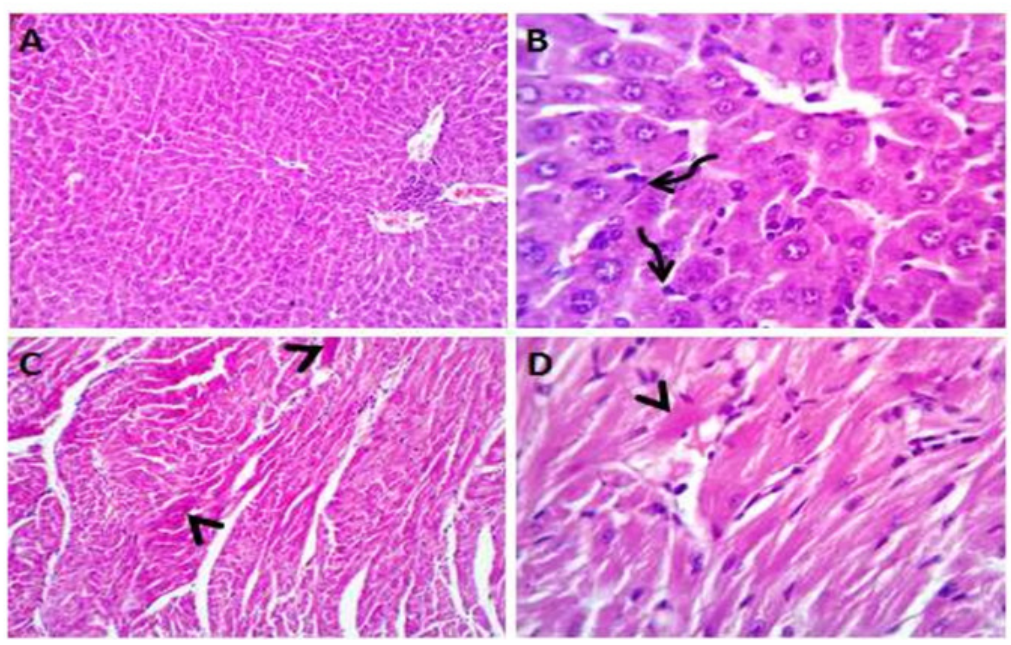




\section{Figure 7}

Photomicrograph of liver sections $(A \& B)$ showing normal hepatic cords, sinusoids and prominent kupfffur cells. Heart sections $(C \& D)$ showing mild interstitial edema (stars) and myocardial degeneration (curved arrow). H\&EX 100(A, C), 400(B, D)

Photomicrograph of liver sections $(A \& B)$ showing normal hepatic cords, sinusoids and prominent kupfffur cells. Heart sections $(C \& D)$ showing mild interstitial edema (stars) and myocardial degeneration (curved arrow). H\&EX 100(A, C), 400(B, D) 


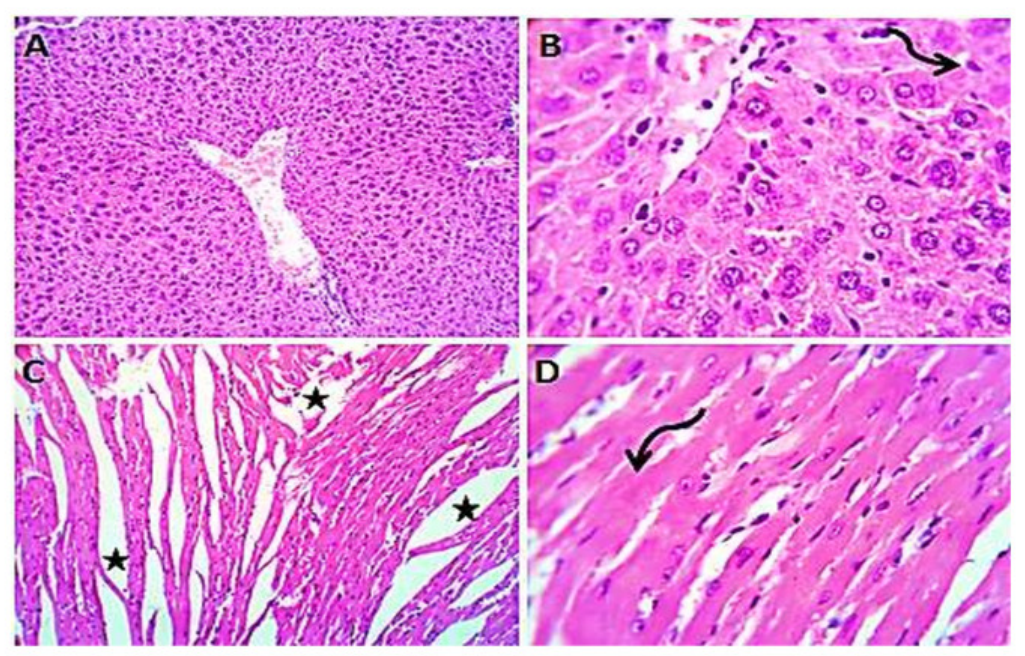




\section{Figure 8}

Photomicrograph of liver (A, B, C \& D) showing wide spread centrolobular (curved arrow) micro (closed arrows) and macro steatosis (arrow head) beside portal round cells aggregation (open arrow). Heart sections $(E \& F)$ showing mild congestion of the corona

Photomicrograph of liver (A, B, C \& D) showing wide spread centrolobular (curved arrow) micro (closed arrows) and macro steatosis (arrow head) beside portal round cells aggregation (open arrow). Heart sections $(E \& F)$ showing mild congestion of the corona 


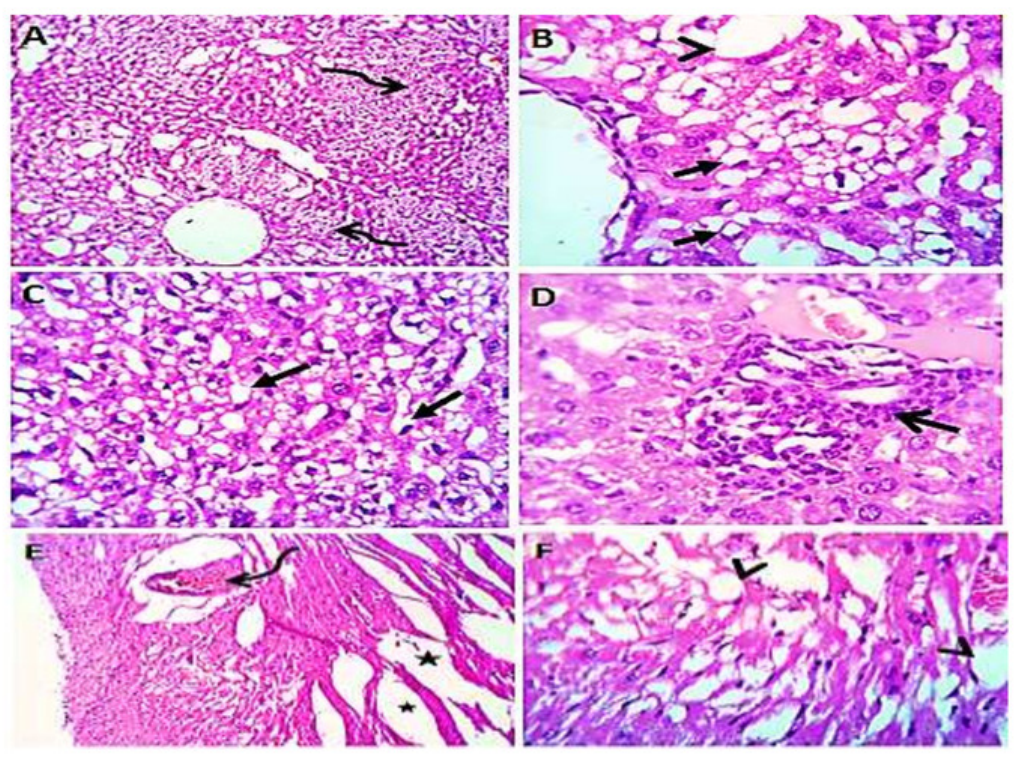




\section{Figure 9}

Photomicrograph of liver showing wide spread centrolobular (curved arrow) micro steatosis (closed arrow). Heart sections (C\&D) showing mild congestion of the coronary blood vessels (curved arrows), interstitial edema (stars) and micro steatosis

Photomicrograph of liver showing wide spread centrolobular (curved arrow) micro steatosis (closed arrow). Heart sections $(C \& D)$ showing mild congestion of the coronary blood vessels (curved arrows), interstitial edema (stars) and micro steatosis (arrow heads) in a moderate number of cardiomyocytes. H \& EX $100(A, C), 400$ (B, D) 


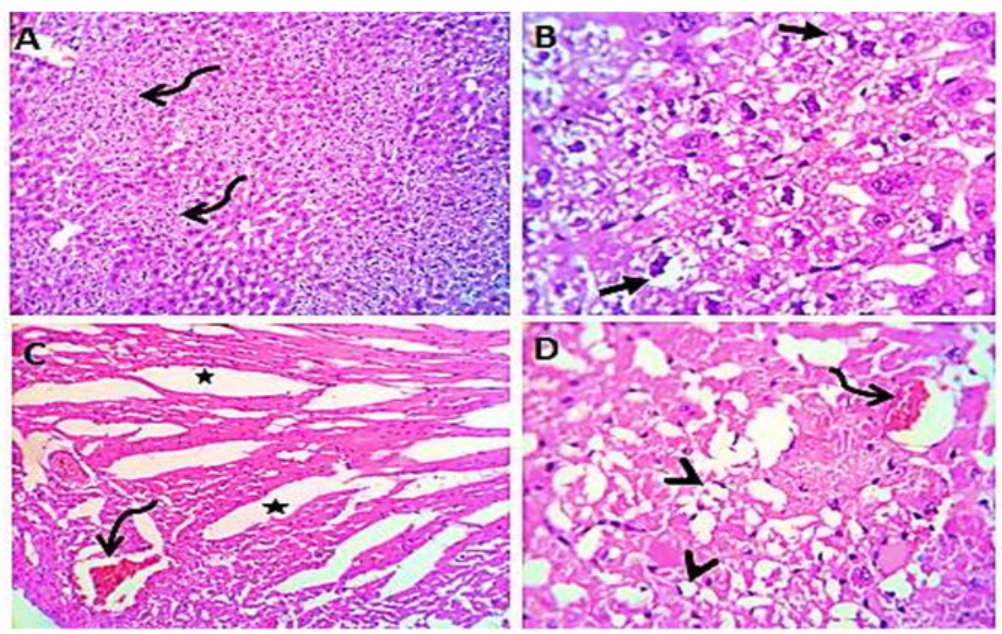




\section{Figure 10}

Photomicrograph of liver $(A, B, C \& D)$ showing congestion of hepatic blood vessels (star) with perivascular leukocytic infiltration (open arrow) mainly neutrophils (arrow head)

Photomicrograph of liver ( $A, B, C \& D)$ showing congestion of hepatic blood vessels (star) with perivascular leukocytic infiltration (open arrow) mainly neutrophils (arrow head) in addition to extravasated erythrocytes (curved arrow). Sections from the heart (E \& F) showing sever congestion of coronary blood vessels (curved arrow), interstitial edema (stars) beside steatosis (closed arrows) and hyaline degeneration (arrow heads) of some cardiomyocytes. $H \& E X 100(A, B), 400$ (C, D, E \& F) 


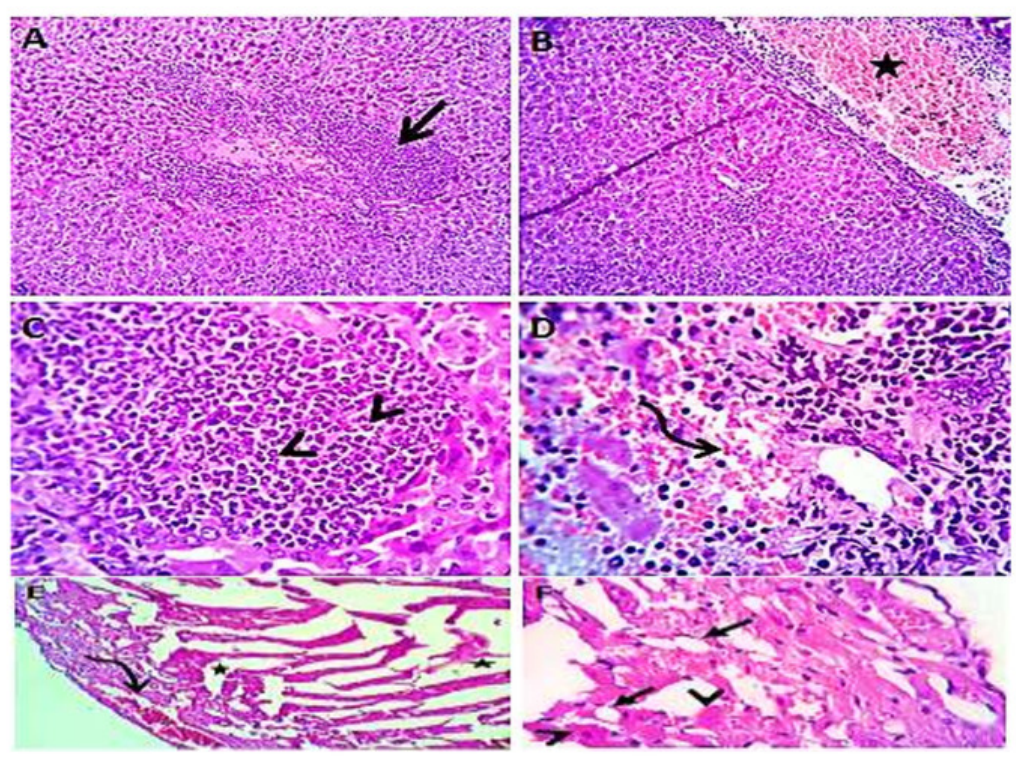




\section{Figure 11}

Photomicrograph of liver $(A \& B)$ showing apparently normal hepatic parenchyma with preserved lobules, cords and sinusoids beside presence some apoptotic (arrow head) and degenerated (open arrow) cells. Heart sections(C\&D) showing normal cardiomyocytes

Photomicrograph of liver $(A \& B)$ showing apparently normal hepatic parenchyma with preserved lobules, cords and sinusoids beside presence some apoptotic (arrow head) and degenerated (open arrow) cells. Heart sections $(C \& D)$ showing normal cardiomyocytes with mild interstitial edema (stars) and hyaline degeneration in some cells (curved arrow). H\& EX $100(A, C), 400(B, D)$ 


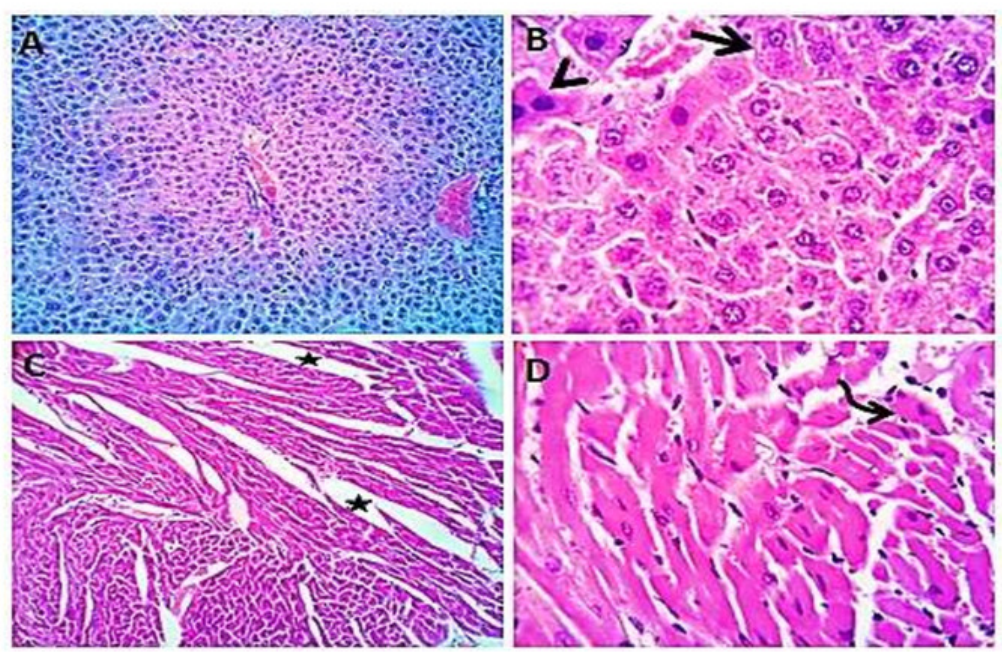




\section{Table 1 (on next page)}

Modified constituents of Zarrouk's medium 


\section{Table (1)}

2 Modified constituents of Zarrouk's medium

\begin{tabular}{ll}
\hline Constituent $\mathbf{A}$ & $\mathbf{g} / \mathbf{L}$ \\
\hline $\mathrm{NaHCO}_{3}$ & 18 \\
\hline $\mathrm{NaNO}_{3}$ & 2.5 \\
\hline $\mathrm{K}_{2} \mathrm{SO}_{4}$ & 1 \\
\hline $\mathrm{NaCl}$ & 1 \\
\hline $\mathrm{K}_{2} \mathrm{HPO}_{4}$ & 0.5 \\
\hline $\mathrm{MgSO}_{4} \cdot 7 \mathrm{H}_{2} \mathrm{O}$ & 0.2 \\
\hline $\mathrm{Na}_{2} \mathrm{EDTA}$ & 0.08 \\
\hline $\mathrm{CaCl}_{2}$ & 0.04 \\
\hline $\mathrm{FeSO}_{4} \cdot 7 \mathrm{H}_{2} \mathrm{O}$ & 0.01 \\
\hline $\mathbf{C o n s t i t u e n t ~}^{\mathbf{B}}$ & $\mathbf{1} \mathbf{~ \mathbf { l }} / \mathbf{L}$ \\
\hline Trace elements & $\mathbf{g} / \mathbf{L}$ \\
\hline $\mathrm{H}_{3} \mathrm{BO}_{3}$ & 2.860 \\
\hline $\mathrm{MnCl}_{2} \cdot 4 \mathrm{H}_{2} \mathrm{O}$ & 1.800 \\
\hline $\mathrm{ZnSO}_{4} \cdot 7 \mathrm{H}_{2} \mathrm{O}$ & 0.220 \\
\hline $\mathrm{Cu}_{2} \mathrm{SO}_{4}$ & 0.080 \\
\hline$\left(\mathrm{NH}_{4}\right)_{6} \mathrm{Mo}_{7} \mathrm{O}_{24} \cdot 4 \mathrm{H}_{2} \mathrm{O}$ & 0.020 \\
\hline
\end{tabular}

3

4 
Table 2 (on next page)

table 2

Experimental groups of mice and diets used in the feeding study 
1 Table (2)

2 Experimental groups of mice and diets used in the feeding study

3

\begin{tabular}{lll}
\hline Groups & Diet & Formulation \\
\hline I & cholesterol-free diet & $1 \mathrm{~kg}$ basal diet ${ }^{*}+500 \mathrm{~mL}$ water \\
\hline II & S. platensis & $1 \mathrm{~kg}$ basal diet $+500 \mathrm{~mL}$ water + S. platensis $(15 \mathrm{mg} / \mathrm{mL})$ \\
\hline III & cholesterol-enriched diet & $1 \mathrm{~kg}$ basal diet $+500 \mathrm{~mL}$ water $+1 \mathrm{~g}$ cholesterol \\
\hline IV & Cholesterol-enriched diet $+S$. & $1 \mathrm{~kg}$ basal diet $+500 \mathrm{~mL}$ water +1 g cholesterol $+S$. \\
& platensis & platensis $(15 \mathrm{mg} / \mathrm{mL})$ \\
\hline V & Cholesterol-enriched diet + & $1 \mathrm{~kg}$ basal diet $+500 \mathrm{~mL}$ water $+1 \mathrm{~g}$ cholesterol +10 \\
& atorvastatin & $\mathrm{mg} / \mathrm{kg}$ atorvastatin \\
\hline VI & Cholesterol-enriched diet $+S$. & $1 \mathrm{~kg}$ basal diet $+500 \mathrm{~mL}$ water +1 g cholesterol $+S$. \\
& platensis + atorvastatin & platensis $(7.5 \mathrm{mg} / \mathrm{mL})+5 \mathrm{mg} / \mathrm{kg}$ atorvastatin \\
\hline
\end{tabular}

*Basel diet composition according to Reeves et al., (1993)

5 


\section{Table 3(on next page)}

table 3

The effect of cultivation in colored glass bottles on the growth performance, total carotenoid and chlorophyll a content of $S$. platensis 


\section{Table (3)}

2 The effect of cultivation in colored glass bottles on the growth performance, total carotenoid and 3 chlorophyll a content of S. platensis

4

\begin{tabular}{lccccc}
\hline \multirow{2}{*}{$\begin{array}{l}\text { Flask } \\
\text { color }\end{array}$} & $\begin{array}{c}\text { Cell dry weight } \\
\text { ( } / \mathrm{L})\end{array}$ & $\begin{array}{c}\mathrm{mg} / \mathrm{g} \\
\text { (dry weight) }\end{array}$ & $\begin{array}{c}\% \\
(\text { dry weight) }\end{array}$ & $\begin{array}{c}\mathrm{mg} / \mathrm{g} \\
(\text { dry } \\
\text { weight })\end{array}$ & $\begin{array}{c}\text { Total carotenoid } \\
\text { (dry } \\
\text { weight })\end{array}$ \\
\hline Colorless & 3.40 & 17.85 & 1.78 & 61.88 & 6.19 \\
\hline Red & 2.60 & 13.65 & 1.36 & 47.32 & 4.73 \\
\hline Blue & 2.18 & 11.45 & 1.14 & 39.68 & 3.97 \\
\hline Green & 2.00 & 10.50 & 1.05 & 36.40 & 3.64 \\
\hline
\end{tabular}

5 


\section{Table 4 (on next page)}

table 4

Volatile compounds identified in methanolic extract of $S$. platensis obtained from colorless flasks by GC-MS 


\section{Table (4)}

2 Volatile compounds identified in methanolic extract of $S$. platensis obtained from colorless flasks by GC3 MS

\begin{tabular}{lllll}
\hline Compound name & Molecular formula & RT $($ min) & Area (\%) & M. Wt \\
\hline Hexamethylcyclotrisiloxane & {$\left[\left(\mathrm{CH}_{3}\right)_{2} \mathrm{SiO}\right]_{3}$} & 03.79 & 1.23 & 222 \\
\hline propanedioic acid (malonic acid), dimethyl ester & $\mathrm{C}_{5} \mathrm{H}_{8} \mathrm{O}_{4}$ & 06.58 & 0.31 & 132 \\
\hline palmitic acid (hexadecanoic acid), ethyl ester & $\mathrm{C}_{18} \mathrm{H}_{36} \mathrm{O}_{2}$ & 26.42 & 0.51 & 284 \\
\hline $\begin{array}{l}\text { 9-Octadecenoic acid, (2-phenyl-1,3-dioxolan-4-yl) } \\
\text { methyl ester, cis- }\end{array}$ & $\mathrm{C}_{28} \mathrm{H}_{44} \mathrm{O}_{4}$ & 27.40 & 0.46 & 444 \\
\hline 10,13-octadecadiynoic acid, methyl ester & & & & 290 \\
\hline 7,10-pentadecadiynoic acid & $\mathrm{C}_{19} \mathrm{H}_{30} \mathrm{O}_{2}$ & 27.81 & 0.56 & 234 \\
\hline hi-oleic safflower oil & $\mathrm{C}_{15} \mathrm{H}_{22} \mathrm{O}_{2}$ & 28.39 & 0.44 & 450 \\
\hline 9-octadecenoic acid (Z)-, phenylmethyl ester & $\mathrm{C}_{21} \mathrm{H}_{22} \mathrm{O}_{11}$ & 29.41 & 0.66 & 372 \\
\hline $\begin{array}{l}\text { palmitic acid, (2-phenyl-1,3-dioxolan-4-yl) methyl } \\
\text { ester }\end{array}$ & $\mathrm{C}_{25} \mathrm{H}_{40} \mathrm{O}_{2}$ & 29.81 & 0.69 & 418 \\
\hline isochiapin b & $\mathrm{C}_{26} \mathrm{H}_{42} \mathrm{O}_{4}$ & 31.74 & 0.35 & 346 \\
\hline dimethoxyglyceroldocosyl ether & & & & 460 \\
\hline oxiraneundecanoic acid, 3-pentyl-, methyl ester & $\mathrm{C}_{19} \mathrm{H}_{22} \mathrm{O}_{6}$ & 32.78 & 3.81 & 312 \\
\hline oleic acid, eicosyl ester & $\mathrm{C}_{27} \mathrm{H}_{56} \mathrm{O}_{5}$ & 32.92 & 02.1 & 562 \\
\hline 17-pentatriacontene & $\mathrm{C}_{19} \mathrm{H}_{36} \mathrm{O}_{3}$ & 33.39 & 2.32 & 490 \\
\hline 9-hexadecenoic acid, eicosyl ester, (Z)- & $\mathrm{C}_{38} \mathrm{H}_{74} \mathrm{O}_{2}$ & 33.86 & 0.52 & 534
\end{tabular}

\section{4 "retention time}




\section{Table 5 (on next page)}

table 5

Relativeweight gain of the control and experimental animals of male Swiss Albino (SA) mice fed a high-cholesterol diet and differentS. platensis formulations for 5 weeks 


\section{Table (5)}

2 Relative weight gain of the control and experimental animals of male Swiss Albino (SA) mice fed a high-

3 cholesterol diet and different $S$. platensis formulations for 5 weeks

\section{Animal group/treatments \\ Initial weight}

(g)

I. Control

II. S. platensis $(15 \mathrm{mg} / \mathrm{mL})$

III. Cholesterol (10\%)

IV. Cholesterol $(10 \%)+$ S. platensis $(15 \mathrm{mg} / \mathrm{mL})$

V. Cholesterol $(10 \%)+$ atorvastatin $(10 \mathrm{mg} / \mathrm{kg})$

VI. Cholesterol $(10 \%)+S$. platensis $(7.5 \mathrm{mg} / \mathrm{mL})+$ atorvastatin $(5 \mathrm{mg} / \mathrm{kg})$

\section{Final weight Body weight gain}

(g)

\begin{tabular}{ccc}
\cline { 2 - 3 } & $\mathbf{g}$ & $\mathbf{\%}$ \\
\hline $2.00 \pm 0.38^{\mathbf{a}}$ & $4.00 \pm 0.23^{\mathbf{a}}$ & 13.33 \\
\hline $2.68 \pm 0.12^{\mathbf{b}}$ & $-4.32 \pm 0.24^{\mathbf{b}}$ & -14.90 \\
\hline $2.00 \pm 0.50^{\mathbf{a}}$ & $2.00 \pm 0.10^{\mathbf{a}}$ & 6.66 \\
\hline $6.53 \pm 0.42^{\mathbf{b}}$ & $-7.34 \pm 0.45^{\mathbf{c}}$ & -23.68 \\
\hline $2.49 \pm 0.34^{\mathbf{b}}$ & $-3.47 \pm 0.50^{\mathbf{b}}$ & -11.57 \\
\hline & $-4.51 \pm 0.20^{\mathbf{b}}$ & -16.11
\end{tabular}

4 "data are expressed as mean \pm standard deviation.

5 values in the same column with different superscript letters are significantly different $(p<0.05)$ 